\title{
Pelagius' View of Ideal Christian Women in his Letters
}

\section{Critical Perspectives of Recent Pelagian Studies Comparing Chrysostom's View in his Letter to Olympias}

\author{
Nozomu Yamada \\ Professor, Department Policy Studies, Nanzan University, Nagoya, Japan \\ nozomu@nanzan-u.ac.jp
}

\begin{abstract}
The Pelagians' ascetical practices were aiming at neither a kind of elitism nor perfectionism, rather, they simply tried to instruct their women disciples on the physical and spiritual care management in Eastern Christian ascetic manners. Pelagius emphasized the free will of women and their dignity as being in the image of God. This was quite different from the negative evaluations of women's free will by Jerome, Augustine, and later Western priests, but quite similar to the affirmative perspectives of women's freedom of will by Eastern Church fathers like John Chrysostom. In this presentation, I would like to focus on the letters to Demetrias from Jerome, Pelagius, and Ps. Prosper; Pelagius' letters to a widow and a married woman; and Chrysostom's letter to Olympias. Critically considering the previous research on the letters to Demetrias (by A.S. Jacobs 2000, A. Kurdock 2003 and 2007, and K. Wilkinson 2015), I would like to evaluate the unique perspective that Pelagius offers of the ideal woman as described in the letters to Christian women, from an Eastern theological viewpoint.
\end{abstract}

\section{Keywords}

Pelagius - Demetrias - Chrysostom - Olympias - Christian Woman

\section{$1 \quad$ Introduction}

The fourteen-year girl Demetrias of gens Anichii, a preeminent wealthy Roman noble family, decided to take the veil and was consecrated in 414 , in 
Chartage, where she had come to take refuge from the invasion of Rome by Goth Alaric. Before Demetrias' consecration, her mother Juliana had asked several Christian thinkers to write her a letter encouraging her decision. It was Pelagius who immediately responded Juliana's request. Thereafter, Jerome and Augustine also wrote to her and her family. Augustine did not write directly, but he wrote letters to Demetrias' mother Juliana and grandmother Proba. ${ }^{1}$

Writing a letter to Demetrias or her family was a touchstone for judging not only the author's view of the ideal Christian woman, but also even the author's orthodoxy or heresy. Even when Pelagius wrote his letter to Demetrias, he was clearly conscious of the traducianists who seemed him to look down on human nature and he warned her of such pessimists, perhaps like Jerome or Augustine. On the other hand, Jerome and Augustine also warned her against the Pelagian "heresies", the opportunists believing in human nature and the power of human free will. Nevertheless, it is obvious that those letters to Demetrias represent essential touchstones not only for the writers of these letters but also for their modern readers or interpreters.

In this presentation, I shall first offer criticisms of three previous modern researchers, A.S. Jacobs (2000), ${ }^{2}$ A. Kurdock $(2007)^{3}$ and K. Wilkinson (2015), ${ }^{4}$ all of whom also considered the letters to Demetrias and her family by Pelagius, Jerome, and Ps. Prosper. ${ }^{5}$ Then I will consider Pelagius' letters to Demetrias and other adult women and explore their significance by comparing Pelagius' view of the ideal Christian woman with the ascetical exhortations of John Chrysostom's letter to the deaconess Olympias. ${ }^{6}$ The ultimate purpose of this presentation is to make clear that Pelagius is the person who continued to advocate for Christian women to be independent, as they had been in the Early Church.

1 Concerning the circumstances, in which Pelagius and Jerome send their letters to Demetrias, see; B.R. Rees, The Letters of Pelagius and his Followers, Woodbridge, 1991, p. 34. Pelagius, Epistula ad sacram Christi virginem Demetriadem; PL 30, 15-45: Hieronymus, Epistula $130=$ CSEL 56, pp. 175-201.

2 A.S. Jacobs, "Writing Demetrias : Ascetic logic in Ancient Christianity," Church History, Vol. 69, No.4 (2000), pp. 719-748.

3 A. Kurdock, "Demetrias ancilla dei ; Anicia Demetrias and the problem of the missing parton," in: Religion, Dynasty, and Patronage in Early Christian Rome, 3oo-goo, ed. K. Cooper, J. Hillner, Cambridge, 2007, pp. 190-224.

4 K. Wilkinson, Women and Modesty in Late Antiquity, Cambridge, 2015.

5 Ps.-Prosper, Epistula ad Demetriadem De Vera Humilitate; PL 55, 161-80; K.C. Krabbe, "Epistula ad Demetriadem, De Vera Humilitate: a critical text and translation with introduction and commentary," Catholic University of America, Patristic Studies 97, Washington, DC. 1965, pp. $47-52$.

6 John Crysostom, Epistolae, TH $\triangle E$ EПIOINH MOY, I-XVII; PG 52, 549-623, English translation, D.C. Ford, Saint John Chrysostom, Letters to Saint Olympia, St. Vladimir's Seminary Press, Yonkers, New York, 2016. 
A.S. Jacobs took for the first time the letters of Pelagius, Jerome, Augustine and released his comparative study titled, "Writing Demetrias: Ascetic Logic in Ancient Christianity" (2000). Jacobs explored two main questions in his study; the first one was how the particular "asceticisms" of three thinkers respond to and attempt to transform Demetrias's inescapable social position. According to Jacobs, who conducted his research through the concept of "agency", Pelagius tried to transfer her social nobility into a new ascetic Christian order, in which her social "rank and honor" were forever transformed into a vision of Christian elitism. ${ }^{7}$ Jerome also took the same direction as Pelagius to transform her secular hierarchy into Christian nobility. Nevertheless, Jerome entrusted the transformation of Demetrias to her mother and grandmother. ${ }^{8}$ On the other hand, "Augustine deliberated deflated her nobility", emphasizing that the sanctity of her belonging not to herself but to God. ${ }^{9}$ Jacobs' second question was "how these three men construct Demetrias's virginal devotion as a function of both theory (theology) and praxis (asceticism)". ${ }^{10}$ Jacobs argued that for Pelagius both theory and praxis functioned integrally, whereas for Jerome, theory being left to Demetrias's adult family members, only ascetic practices should be set to her. On the other hand, for Augustine, neither theory nor praxis should be imposed on Demetrias because "good deeds are in her but not of her", only from God's grace."1

A. Kurdock's research, "Demetrias ancilla dei: Anichia Demetrias and the problem of the missing patron" (2007) treated the letters of three thinkers consequently not from a theological but from a historical perspective. Her concerns focused not only on political negotiations of the three churchmen but particularly also on their financial interests. ${ }^{12}$ Kurdock concludes, "it seems plain that each of these three outstanding figures of the church are concerned with the possibility that any other of them might receive financial support". ${ }^{13}$ Kurdock's study made clear much other important historical evidence. Here in relation to this paper it would be sufficient to indicate Augustine's words to warn Juliana Demetrias' mother against Pelagius; "In this book (Pelagius' letter) (...) a virgin of Christ would read that her holiness and all her spiritual

\begin{tabular}{ll}
\hline 7 & Jacobs, p. 728. \\
8 & Ibid., p. 731. \\
9 & Ibid., p. 734. \\
10 & Ibid., p. 735. \\
11 & Ibid., p. 742. \\
12 & Kurdock, p. 200. \\
13 & Ibid., p. 210.
\end{tabular}


riches are to spring from no other source than herself, and thus, before she attains to the perfection of blessedness, she would learn to be ungrateful to God". ${ }^{14}$ Just after hearing this, Juliana, patron of Pelagius, defended herself and answered to Augustine, "But your Reverences knows that I and my household are entirely separated from persons of this description; and all of our family follow so strictly the Catholic faith as never at any time to have wandered from it, or fallen into any heresy".15 These texts indicate that Juliana was firmly convinced of Pelagius' authenticity as a Catholic.

K. Wilkinson released the first book-length treatment of the three Latin writers' letters to Demetrias, titled "Women and Modesty in Late Antiquity" (2015). Wilkinson, as a feminist historiographer, chose a key-concept 'modesty', one of typical terminologies in ancient Rome, and using this concept, she analyzed Christian female ethos (clothing, domesticity, speech and free will). Moreover, she broadened her academic field not only from a patristic perspective but also to incorporate a cultural-anthropological perspective, and compared Pelagius' women ethos with other cultural women's ethos. Concerning ascetic clothing and taking the veil, ${ }^{16}$ Wilkinson investigated Jerome's and Pelagius' ideas, but concerning the concept of choice of women's free will, Augustine's and Pelagius' understandings were investigated. Wilkinson noticed Pelagius' emphasis on women's free choice. ${ }^{17}$ Augustinian and Pelagian understandings were taken into consideration. Wilkinson made clear Pelagius' emphasis on female's free choice by their own will. Nevertheless, quoting Augustine's words; 'because indeed it is from her own free choice, without which we do no good action, but not, however, as this man (Pelagius) said, "only from her", 18 Wilkinson finally demonstrated Augustine's critique to Pelagius, saying "Demetrias has a choice, but she can only make the right choice by the gift of God. God's grace frees the will, which, enslaved to sin could only make ignorant and harmful choices. A sinful choice is never a truly free choice in Augustine's thought-world". 19

These three previous researchers' works are good works, but to my thinking, overlook three important viewpoints. First, all three researchers did not notice or simply ignored that Pelagius was strongly influenced by the Eastern theo-

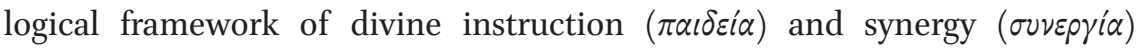

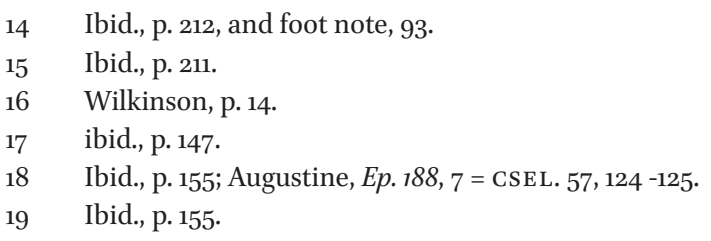


between God and human beings, that is $\vartheta \dot{\varepsilon} \omega \sigma \iota{ }^{20}$ Therefore, particularly Wilkinson, in dealing with female choice, made exactly the same error as Augustine did. As a result, she could not help repeating typical Augustinian logic, that is, 'Pelagius said, good action was "only from her". If we read Pelagius' letter free from Augustine's prejudice it is quite obvious that Pelagius did not have such a one-sided opinion. ${ }^{21}$

Second, all three researchers did not refer at all to the fact that Pelagius stated several times in the letter the equality of men and women in free will. ${ }^{22}$ Among four Latin writers, it was only Pelagius that asserted clearly the equality of men and women in human free will. I wonder why Wilkinson, self-acknowledged feminist historiographer ignored this significant fact.

Third, except for Kurdock, the other two researchers overlook a political viewpoint to Pelagius' letter. Particularly, Wilkinson denies the political character of Pelagius assertions, saying; "when Pelagius spoke of freedom he did not have in mind political freedom or social equality". ${ }^{23}$ Asking "freedom from what?", ${ }^{24}$ Wilkinson went further; "the freedom of which Pelagius writes has much more in common with the freedom promised in contemporary self-help manuals than with the analytics of power and oppression in the gender system". ${ }^{25}$ She concludes, "When Pelagius spoke of freedom he did not have in mind political freedoms or social equality". ${ }^{26}$ In my view, this is nothing but a flagrant misunderstanding. Wilkinson does not seem to notice that Pelagius made moral exhortations to Demetrias with a strong critical viewpoint against the "corrupted reality" of the Roman Church. It is understandable for us to read Pelagius' following description, which Wilkinson ignored in her book of "Modesty"; "It is very easy to wear a modest garment, (...) to promise humility and gentleness (...) at every word to proclaim oneself a miserable sinner, then if

20 Concerning the relationship between Pelagius and Eastern theological framework, see N. Yamada, "What Is the Evil to Be Overcome? Differences between Augustine's and Pelagius' Views on Christ's Life and Death," Scrinium 11 (2015), particularly its Chapter 2 and 3, pp. 161-175. The influence of Greek Fathers on Pelagius' theology and anthropology has long being pointed out. T. Bohlin, Die Theologie des Pelagius und ihre Genesis, Uppsala Wiesbaden, 1957, and G. Greshake, Gnade als konkrete Freiheit. Eine Untersuchung zur Gnadenlehre des Pelagius, Mainz, 1972, are especially important.

21 Cf., Chapter 3.2 "Synergy"and "Perfection" as "Individualization" of this article.

22 N. Yamada, "Equality of Men and Women in Free Will: The Narrative Technique of Pelagius' Letters and Pauline Commentaries," in: Men and Women in the Early Christian Centuries, ed. W. Mayer and I.J. Elmer (Early Christian Studies 18), Strathfield, 2014, pp. 251-270.

23 Wilkinson, p. 143.

24 Ibid., p. 144.

25 Ibid., p. 146-147.

26 Ibid., p. 143. 
offended by a frivolous speech, lift one's neck and suddenly exchange that refined tone of voice for a wild shout. It was another sort of humility that Christ taught us. (...) Endurance of insult reveals the truly humble". ${ }^{27}$

In order to criticize previous research, and also to compensate for their shortcomings, I would like to evaluate again the peculiarity of Pelagius' view of the ideal woman described in the letter to Demetrias and other female disciples of Pelagius from an Eastern theological viewpoint. Moreover, for proving that Pelagius developed not a novel heretic view, particularly in emphasizing women's free will, I would like to introduce John Chrysostom's letter to the deaconess Olympias.

\section{Pelagius' letter to Demetrias}

\subsection{Women's Dignity and Free Will}

At the beginning of his letter to Demetrias, Pelagius draws Demetrias' attention to human nature and free will, which God had created. "First, then, you ought to measure the good of human nature by reference to its creator, I mean God. (...) God determines to fashion him in his own image and likeness and shows what kind of creature he intends to make him. (...) The Lord of Justice wished man to be free to act and not under compulsion". ${ }^{28}$ We have to pay attention to the fact that Pelagius emphasized the human free will not as a precondition for getting God's grace, but conversely, as God's gift of grace.

Secondly, we should note Pelagius' emphasis on the equality of men and women with regard to their free will. It is "on this freedom to choose either alternative, that the glory of the rational mind is based, (...), it is from this that its dignity is derived". In Pelagius' thought, not only men but also women maintain human dignity, and both can equally make their free will work to anticipate equal future rewards from God. "Though it may appear to refer to men

27 Pelagius, ad Dem. 20.1; PL 30, 34-35; "Perfacile est enim aliquam vestem habere contentam salutare submissius, manus et genua deosculari, inclinato in terram capite, oculisque dejectis, humilitatem ac mansuetudinem polliceri, lenta voce tenuique sermones infringere, suspirare crebrius, et ad omne verbum peccatorem ac miserum se clamare. Et si vel levi sermone offensus sit, continuo attollere supercilium, levare cervicem, et delicatum illum oris sonum insano repente clamore mutare. Aliam nos humilitatem Christus docuit, qui nos ad exemplum suum hortatur, (...) Verum humilem patientia ostendit injuriae."

Pelagius, ad Dem. 2.2; PL 30, 17; "Quem dum ad imaginem et similitude suam facere disponit, antequam faciat, qualem sit facturus, Ostendit. Quem tamen justitiae exsecutorem Dominus voluntarium esse voluit, non coactum." 
only, yet it is not addressed to men alone; rather, an equal reward for virginity is promised to both sexes". 29

\section{2 "Synergy" and "Perfection" as "Individualization"}

The other peculiarity of Pelagius' moral counsel is not to leave human nature and free will unworkable, but to make them work as much as possible. It is important for Demetrias, not to seek to accomplish only her will but more than anything else to seek God's will by exercising her own free will. Pelagius advises her, "Do not let yourself be deceived by the examples of those women who, while applauding themselves on their chastity alone, reject the will of God and follow the dictates of their own wills". 30

Pelagius asserted that several women made their escapes from accomplishing God's will on the pretext of the weakness of their nature, but in Pelagius' thinking, "No one knows better the true measure of our strength than he who has given it to us". ${ }^{11}$ Pelagius' main message here is that human nature is not so weak as to be incapable of God's commandments, as is evident in another letter to Claudia, "But neither is anything beyond your powers being enjoined on you: he who has done what he could has done everything". ${ }^{2}$

Here, it is very obvious that Pelagius did not require women not unrealizable perfection but possible completeness; that is, what they could achieve themselves. Pelagius did not advocate flawless perfectionism, but he only wanted women to use their free will to seek God's will as much as possible. "This very capacity to do evil is also good - good, I say, because it makes the good part better by making it voluntary and independent, not bound by necessity but free to decide for itself". ${ }^{33}$

Moreover, Pelagius advises Demetrias so that she could individualize and personalize more and more, in proportion to making her similar to God's image. "If you wish to make the extent of your intention (...) to be joined with God in everything, if you wish to make the light, agreeable yoke of Christ, (...) now

29 Pelagius, ad Dem. 9.3; PL 30, 24-25: "Quamquam de viris tantum sonare videatur, non solis tamen viris dicitur, sed aequalis utrique sexui virginitatis palma promittitur."

30 Pelagius, ad Dem. 10.2; PL 30, 25 : "Nec te earum exempla decipiant, quae sib in sola castitate plaudentes, ut post suas voluntates eant,Dei voluntatem abjiciunt."

$31 \quad$ Pelagius, ad Dem. 16.3; PL 30, 31: "Nemo magis novit mensuram virium nostrarum, quam qui ipsas vires nobis dedit. Nec quisquam melius quantum possimus intelligit, quam qui ipsam virtutem bovis nostri posse donavit."

Pelagius, Epistula ad Claudiam de virginitate 6; CSEL 1, p. 232: "uerum nec tibi aliquid inpossibile imperatur: impleuit Omnia qui quod potuit fecit."

33 Pelagius, ad Dem. 3.2; PL 30, 18: "Quod cum ita sit, hos quoque ipsum quod etiam mala facere possums, bonum est. Bonum, inquam, quia boni partem meliorem facit. Facit enim ipsam voluntariam sui juris : non necessitate devinctam, sed judicio liberam." 
apply yourself to (...) be kindling the glowing faith of your recent conversion. (...) Whatever you implant in yourself at the outset will remain, and the rest of your life will run along on the course set by your beginning. At the very commencement the end has to be kept in mind: try even now to be the kind of person you want to be when you reach the last day. (...) the habit of doing good must be exercised and strengthened by the practice of constant meditation, (...) the practice of holy conduct must be implanted at a deeper level. Then indeed the mind (...) uses the advantage of long habit so as to acquire the ability to live well and, marveling at its own qualities, will come to suppose that what it has learned was actually born with it or, in some measure, within it".34 Pelagius explains here in a more practical manner how ovvepyía of God and human beings functions, and how inherent capacities and characters should be individualized and personalized through leading by God's grace, faith and also Holy Spirit. Pelagius clearly assures in other documents that human will should be aided by Christ example, which is a typical term of Pelagius indicating God's grace and also Holy Spirit. ${ }^{35}$

In addition to this, we have to note that Pelagius emphasized several times in the letter the spiritual illumination by God's word; "That is why your soul must be illuminated by divine utterances, (...) for the devil is quick to flee from the soul which is illuminated by divine speech, which is always occupied with heavenly thoughts, in which God's word, whose force the evil spirit is unable to endure, is constantly present". ${ }^{36}$ Here also we can recognize clearly an Eastern type of seamless Synergy between God's spiritual illumination and human endeavor by free will for receiving illumination by God. Just through this Synergy, Pelagius stresses, Demetrias can distinctly repulse the demonic power of evil.

Here, it is quite important, distinguishing God's grace and human free will, to note that Pelagius did not cut them off nor separate both but rather he made both mutually permeate and he posted both God's grace and human free will

34 Pelagius, ad Dem. 13; PL 30, 28: "Si visitaque propositi tui magnitudinem aequare moribus, et per Omnia Deo copulari : si leve ac suave jugum Christi, suavius tibi leviusque vis facere : nunc maxime in beata vita curam impende : nunc stude, ut calentem recentis fidem conversionis, novus semper ardor accendat, et in tenera adhuc aetate facilius sanctae converstionis usus inolescat. Quidquid in te primum instituteris, hoc manebit, et ad initiorum tuorum regulam reliqua vita decurret. Finis in ipso exordio cogitandus est. Qualis ad illum ultimum diem pervenire cupis, talis nunc jam esse conare."

35 For example, Pelagius, ad Dem. 25; PL 30, 40: "Ostendit quomodo resistere debeamus diabolo, si utique simus subditi Deo, ejusque faciendo voluntatem, ut divinam etiam mereamur gratiam : et facilius nequam spiritui, auxilio sancti Spiritus resistamus."

36 Pelagius, ad Dem. 26, 2; PL 30, 40: "illuminenda divinis eloquiis anima : et coruscante Dei verbo, diaboli repellendae sunt tenebrae.Cito enim fugit ille ab ea anima, quam sermo divinus illuminat, quae coelestibus semper cogitationibus occupatur in qua assiduum est Dei verbum, eijus vim nequam spiritus non potest ferre." 
in a seamless continuity. On the other hand, having emphasized corrupt human nature and distorted human free will since Adam's Fall, Augustine separated God's Grace and human free will, and made them discontinuous. Therefore, how Pelagius stressed the Synergy between God and humanity and the work of free will, it seemed to Augustine only vain human endeavors, that they were trying to reach salvation by themselves. Also when Wilkinson said, "Demetrias' moral merit is hers alone and truly her own", 37 it is only because Wilkinson could not imagine the Synergy of God and human beings nor individualizing in $\vartheta \varepsilon \dot{\varepsilon} \omega \sigma \zeta$, just as Augustine also could not.

\subsection{Encouragements of Ascetic Training to Overcome Structural Evils}

Pelagius asserts that ascetic training like almsgiving and continence should be done to overcome the structural evils of the social oppression of the weak. Contrary to Wilkinson's assumption that "Pelagius' freedom is not political nor social", Pelagius gives ascetic exhortations just for overcoming social evils, that is, for saving poor people and children. In other letters, Pelagius reported the corrupt situation of the Roman Church, for example, "by their judgment many women were made widows when their husbands were unjustly put to death, many were left orphans by the killing of their fathers and, in addition to losing their parents, were reduced to beggary and nakedness". ${ }^{38}$ Pelagius advises Demetrias, "Let your works of mercy provide the justification for the labors of fasting, and your abstinence be made more acceptable because it helps to nourish the poor". 39

We have to pay attention to the fact that Pelagius advised her to engage in ascetic trainings moderately, knowing her physical limits, so that her ascetic deeds would not cause vanity and conceit. "Moderation is best in everything and due sense of proportion is praiseworthy in all circumstances; the body has to be controlled, not broken. Therefore, let holiness be sought in moderation, and fasting, which so weakens the body, be practiced in uncomplicated ways and with all humility of mind, lest they inflate the spirit". ${ }^{40}$ Wilkinson did not refer to this passage at all, and quite differently from her and Jacob's judgments

37 Wilkinson, p. 147.

38 Pelagius, Liber de vita christiana, 3, 2; PL 40, 1035 : "Alii autem qui innumerabilem hominum multitudinem injuste peremerant (...). Et quorum judicio maritis injuste peremptis multae effectae viduae, multi orphani patribus occisis derelicti, quibus praeter orbitatem mendicitas inferebatur et nuditas (...). Duo saevissima et atrocissima uno perpetrantur in tempore; homicidium fit, ut rapina succedat."

39 Pelagius, ad Dem. 22.1; PL 30, 36: "Laborem jejunii tui, misericordiae opera commendent, et abstinentia tua, pauperum refectione sit gratior."

40 Pelagius, ad Dem. 21.2; PL 30, 36: "Optimus est in omni re modus, et laudabilis ubique mensura. Corpus non frangendum, sed regendum est. Sint ergo moderata sancta, et simplicia in omni mentis humilitate jejunia, quae ita attenuent corpus..." 
of Pelagius elitism and meritocracy, Pelagius' ascetic exhortations were not aimed at meritocratic endeavors for acquiring God's grace but quite similarly at Eastern traditional notions of $\dot{\alpha} \pi \dot{\alpha} \vartheta \varepsilon l \alpha$, saying more in detail in case of Pelagius, a similar notion of Evagrian $\mu \dot{\varepsilon} \tau p ı 0 \pi \dot{\theta} \theta \varepsilon$, which made its first concern performing moderate asceticism. Pelagius adapted the Latin "impassibilitas" equivalent to the Greek $\dot{\alpha} \pi \dot{\alpha} \vartheta \varepsilon ı \alpha$ only to God or Christ, and he used another equivalent Latin word "imperturbabilitas" for Christian ascetics. ${ }^{41}$ We should not forget, that Pelagius took these ascetic trainings not only for Christian's self controlling method but also as a kind of countermeasure against demonic oppression of weak people in Roman Churches at that time. Pelagius encourages Demetrias to fight against such demonic power, saying; "since it is possible even for women to triumph in this war, take up these weapons of Paul's (...) He shows how we ought to resist the devil, if we are indeed in submission to God, and, by doing his will, to merit divine grace also and to resist evil spirit more easily with the aid of the Holy Spirit". ${ }^{2}$

In Pelagius' thinking, the final purpose of the spiritual fight is nothing but saying, armed with Paul's spiritual armors, "it is no longer I who lives but Christ who lives in me". By the way, Pelagius expected Demetrias to not only presently participate in synergy work with God through her free will, but also promised her eternal rewards in the future, just as Chrysostom did. ${ }^{43}$ Wilkinson negatively evaluated this promise of postponed rewards and criticized it from the point of view of feminist analysis, ${ }^{44}$ saying, "Their (Pelagius') understanding of final good was not linked to a liberal sensibility about individual political and social freedom". 45 In my view, this assumption is a total misunderstanding of Wilkinson. In the end of the letter, recalling the sack of Rome by Goths, ${ }^{46}$ Pelagius asks, "even if we were to reach the last day of our whole life still in daily enjoyment of the pleasure given by luxuries, of what value is that long

$41 \quad$ N. Yamada,'The Influence of Chromatius and Rufinus of Aquileia on Pelagius - as seen in his Key Ascetic Concepts: exemplum Christi, sapientia and imperturbabilitas.' Studia Patristica, vol. LXx, Leuven (2013), pp. 667-668.

42 Pelagius, ad Dem. 25; PL 30, 39-40: "Et quoniam de hoc bello licet etiam feminis triumphare, suscipe haec arma Pauli, et tanti hortatione ducis certam praesume victoriam.(...) Ostendit quomodo resistere debeamus diabolo, si utique simus subditi Deo, ejusque faciendo voluntatem, ut divinam etiam mereamur gratiam : et facilius nequam spiritui, auxilio sancti Spiritus resistamus."

Not only Pelagius but also Chrysostom emphasized that Christian's endurance in the present hardships would bring God's spiritual rewards in the next life. See footnote 51 of this article.

44 Wilkinson, p. 148.

45 Ibid., p. 149.

46 Pelagius, ad Dem. 3o,1; PL 3o, 44. 
stretch of time, if it is destroyed in the end?"47 Pelagius advises Demetrias; "Forget all that is past and think that you are starting afresh each day, and do not reckon the past to be the present day, since it is on the present day that you must serve God". 48

The reasons why I chose Chrysostom's letters to the deaconess Olympias are first, because Chrysostom and Olympias lived just in the same era in the later Roman Empire as Pelagius and Demetrias; secondly, because Olympias belonged to a similar high noble family as Demetrias; and the third reason I chose Chrysostom's letters is because Chrysostom is representative of Antiochian tradition, which, in my view, strongly influenced most Pelagians. Finaly, because, the evaluation of Chrysostom's view on women has been recently reconsidered and changed, although, in contrast to Pelagius, it was often said that Chrysostom's assertions to women were misogynistic. ${ }^{49}$ In recent studies of David Ford, it was made clear that Chrysostom emphasized Christian women's free will and their outgoing attendance in the Synergy of God, which all Eastern theological peculiarities Pelagius also adopted. ${ }^{50}$ Moreover, from the perspective of reconsidering Chrysostom's attitude towards women, particularly reevaluating his view on women, (this article is also taking the same direction), W. Mayer's several recent articles are very significant and important. ${ }^{51}$

47 Pelagius, ad Dem. 29; PL 30, 43: "Et si vita nostra tendatur per mille annnos : et ad extremum illum totius diem aetatis, quotidiana deliciarum voluptate veniamus : quae hoc, quaeso, diu est, quod fine deletur! Aut quis illius voluptatis fructus est, qui statim ut cessaverit, videbitur tibi non fuisse?"

48 Pelagius, ad Dem. 27.4; PL 30, 42: "Obliviscere omne praterium : et quotidie inchoare te puta : ne pro praesenti die, quo debes sevire Deo, prateritum imputes."

49 For example, E.C. Topping, Holy Mothers of Orthodoxy, Women and the Church, Light and Life Publishing Company, Minneapolis-Minnesota, 1987, p. 6: "St John Chrysostom (ob. 407) had a low opinion of women's intellect and capacity for reason. Hence, he declares, it is wise for women to be confined to the home, performing unimportant, undemanding domestic chores (PG 62. col. 500). The golden-tongued archbishop of Constantinople described the female sex as emotional, fickle, superficial, garrulous and servile in temperament (PG 47. cols. 510-511; 61. col. 316; 62. col. 548)."

$50 \quad$ D.C. Ford, "Misogynist or advocate? St. John Chrysostom and his views on women," unpub. PhD diss., Drew University, Madison, MJ, 1989; Id., Women and Men in the Early Church: The Full Views of St. John Chrysostom, South Canaan, Pennsylvania: St. Tikhon's Seminary Press, 1996.

$5^{1}$ W. Mayer, "Constatinopolitan Women in Chrysostom's Circle," Vigiliae Christianae Vol.53, No.3 (Aug., 1999), pp. 265-288; ead., "John Chrysostom and Women Revisited," Men and 
Mayer took up not only the most popular women figures, Eudoxia and Olympias, but also many previously unreferred to names of Christian women with whom Chrysostom was concerned, in quite different circles in Antioch as well as in Constantinople. Making clear every unique characteristic of each Christian women's circle and their patronage relationships with Chrysostom, Mayer conclude, "Just as his preaching and theology are increasingly being shown to be sympathetic in most respects towards women, this overlooked evidence of his actions and attitude towards women at the day-to-day level disproves the charges both of misogyny and of an exclusive interest in ascetic women."52

If we read the letters of Chrysostom to Olympias, we can clearly notice that Chrysostom's letters are all infused with his thoughts that women can also cast aside evil minds and demonic power by their voluntary decisions and by doing so can join in divine instruction and receive future rewards. ${ }^{53}$ When Chrysostom wrote these letters, he was ousted from the post of Archbishop of Constantinople and was sent into exile, and Olympias was also put on trial on preposterous charges while also suffering from various hardships. 54 "So this is what we are hastening to do: not only to banish your despondency, but to fill you with great and continual gladness. This is possible, if you are willing. For the immutable laws of nature do not make it impossible for us to force ourselves to make a change. Rather, the power to manage our own welfare easily lies in the free decisions of our will, and in this our joy resides. (...) For it is certainly not in the nature of things, but in the will of man, that our happiness naturally resides". 55

Olympias confesses her desperate situation of intrigues of opponents to Chrysostom, but he advised her to rebuff her desperate thinking by her making strong decisions. "My lady most beloved by God, take pains, and fight, (...) to repel, to chase away with the utmost ardor, the thoughts troubling you, which are causing you such agitation and such a storm. (...) And now it is necessary to

Women in the Early Christian Centuries, ed. Wendy Mayer and Ian. J. Elmer (Early Christian Studies 18), Strathfield, (2014), pp. 211-225.

$5^{2}$ W. Mayer, ibid., "John Chrysostom and Women Revisited”, p. 225.

53 Chrysostom emphasized that hardships in this life would bring future spiritual rewards. Chrysostom, Ep. to Olympia, 8, 12 A "This is the contest that you are now finishing. However great the contest is, the greater the rewards, the more brilliant the crown"; PG 52, 569:

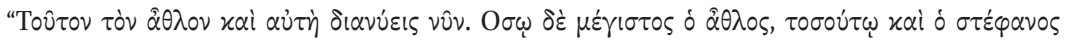

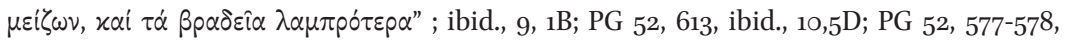
ibid.,10,8C; PG 52, 580, ibid.,10,10B; PG 52, 582.

D.C. Ford, Letters to Saint Olympia, St Vladimir's Seminary Press, Yonkers, New York, 2016, op. cit., p. 19.

55 Chrysostom, Ep.to Olympia, $10 \mathrm{C}$; PG 52, 572-573; D.C. Ford, Letters to Saint Olympia, op. cit., pp. 97-98. 
prepare for you swords and lances, bows and arrows, and breastplates, shields, and leg-armor, in order for you to defend yourself, and to cast down and slaughter and leave for dead the troubling thoughts that assail you". ${ }^{66}$ Chrysostom took her desperate thought for severer difficulties than physical pain or death, and he exhorted her to continue her spiritual fight against desperate thoughts. Chrysostom emphasized that enduring suffering itself was worthy of virtues, and that the virtues would be deserving to receive more love of God. "So on one side were all his virtues, and on the other side all his sufferings. (...) For this was the most bitter part of the battle, requiring the greater courage, the more wellstretched soul, the more philosophic mind, and having greater love for God". 57 In Chrysostom's thinking, Olympia's suffering is nothing but ascetic training, he often referred to "imitation" of his forerunner's "examples", as Pelagius did, "it was through his (Abraham's) wisdom and his (Abraham's) will that he (Abraham) imitated the natural strength of that strongest of substances, and demonstrated through his works the $\dot{\alpha} \pi \dot{q} \vartheta \varepsilon l \alpha$ of angels". ${ }^{8}$ Chrysostom was thinking, just like Apostle Paul who was suffering from hardships and also imitated $\dot{\alpha} \pi \dot{\alpha} \vartheta \varepsilon i \alpha$, the more severe the suffering is, the more the future Grace is, which God had promised.

Pelagius was distinguished among most Latin and Greek Church fathers in stressing the equality of men and women in both the Image of God and free will. Nevertheless, in other peculiarities, emphasizing women's free will and their voluntary decisions, women's attendance to God's instruction, exhortations for ascetic training and future rewards also, Pelagius did not develop novel heretic ideas but asserted rather quite the same confidence as Chrysostom.

Contrary to the letters of Pelagius and Chrysostom to Christian women, the letters to Demetrias and to her families by Jerome, Augustine and Ps. Prosper are commonly lacking in not only the equality of men and women in free will, but also they are decisively lacking in urging women to exercise their free will and to decide for themselves. Conversely, in Jerome's letter, women's inferiority

$5_{6}$ Chrysostom, Ep.to Olympia, 10,2, A; PG 52, 573; D.C. Ford, Letters to Saint Olympia, op. cit. 99 .

57 Chrysostom, Ep.to Olympia, 10,7,C; PG 52, 579; D.C. Ford, Letters to Saint Olympia, op. cit.109.

$5^{8}$ Chrysostom, Ep.to Olympia, 8,7,C; PG 52,563; D.C. Ford, Letters to Saint Olympia, op. cit. 69-70. 
to men in human nature was emphasized and ascetic training include fasting and continence were recommended in the context how women could be freed from domination by sexual desire. ${ }^{59}$ Also in Augustine's letter to Proba, Demetrias' grandmother, women's free will was indeed mentioned but was no longer recommended as the most important concern. On the other hand, Augustine advised Proba becoming an example for the rest of the house hold especially in her role in prayer as an elderly widow. ${ }^{60}$ The necessity of prayer for God's pity was strongly emphasized. ${ }^{61}$

Moreover, Augustine wrote not only to Proba but also to Demetrius' mother Juliana a letter, that is, De bono viduitatis, which was written in about 414 as an answer to her question, how she should live a life of widowhood. ${ }^{62}$ For an interpretation of this letter of Augustine, Goeffrey D. Dunn's article "The Elements of Ascetical Widowhood: Augustine's De bono viduitatis and Epistula 130 " is quite important and helpful. ${ }^{63}$ Augustine recommended fasting and almsgiving to Juliana just as Pelagius did. Nevertheless, Augustine did not emphasize that they should be performed by using her freedom of will, and nor did he assert the equality of men and women in free will. Augustine argued clearly that fasting and almsgiving were a great assistance to prayer. ${ }^{64}$ According to G.D. Dunn's summary, "a rich widow's life of prayer was not a form of renunciation of the world but it enabled her to become involved in world affirmation and transformation. Even though it may not be exclusive to widows, prayer certainly ought to be a feature of Christian life. Perfection in prayer (including the happiness that comes from disinterest in one's possessions) was

59 Hieronymus, Ep.13o,8; CSEL 56, p. 188: "qui uersiculus hunc habet sensum: si in cogitations tuas coluber ascenderit, omni custodia serua cor tuum et cum Dauid canito: ab occultis meis munda me, domine, et ab alienis parce seruo tuo, et ad peccatum maximum, quod opere perpetratur, nequaquam peruenies..."

6o Augustine, Ep.130,30; CSEL 44, p. 76: "quanto enim magis domum uestram pie tractatis, tanto inpensius orationibus instare debetis rerum praesentium non occupatae negotiis, nisi quae flagitat causa pietatis."

61 For example, Augustine, Ep. 130, 10; CSEL 44, pp. 61-63; "Quae cum ita sint, etiam diu orare, cum uacat, id est cum alia bonarum et necessariarum actionum non impediuntur officia, quamuis et in eis, ut dixi, desiderio illo semper orandum sit, non est inprobum nec inutile. neque enim, ut nonnulli putant, hoc est orare in multiloquio, si diutius oretur. Aliud est sermo multus aliud diuturnus affectus. nam et de ipso domino scriptum est, quod pernoctauerit in orando et quod prolixius orauerit. ubi quid aliud quam nobis praebebat exemplum in tempore precator opportunus, cum patre exauditor aeternus?"

62 Augustine, De bono viduitatis $=$ NBA 7/1, $166-215$.

63 Goeffrey D. Dunn, "The Elements of Ascetical Widowhood: Augustine's De bono viduitatis and Epistula 130," in: Prayer and Spirituality in the Early Church, ed. Wendy Mayer, Pauline Allen and Lawrence Cross (The Spiritual Life, Vol. 4), Strathfield, 2006, pp. 247-256.

Augustine, Ep. 130. 13. 24 = NBA 22, 98-100. 
the gift of God to the ascetical Christian." ${ }^{\prime 65}$ Augustine did not deny fasting and almsgiving; rather, he encouraged them as much as Pelagius recommended them. However, their purpose was less for Synergy between God and Human but rather to supplement prayers to God; ultimately, the prayer itself including fasting, almsgiving and whole of human achievements was"the gift of God."

Also in the letter, which was written 26 years later by Ps. Prosper to Demetrias, who already had become Abbess, not women's voluntary decisions but only the necessity of humility before God and male superiors was strongly stressed, with warning against Pelagian heresies. ${ }^{66}$ For historical background about the period in which this letter was written, the authorship of this letter and several characteristics peculiar to the letter, Bronwen Neil's recent article, "On the Humility: An Anonymous Letter on Poverty and the Female Ascetic,"67 is very significant research. Contrary to Pelagius' quite direct critique against wealth and his positive counsel for fasting and almsgiving, Neil conjectures, "the suspicion of Pelagianism may explain our author's concern to refute the notion that the rich cannot attain humility". ${ }^{68}$ Neil pointed out five recurrent themes. Firstly, the author has to make the link between true humility and "true" poverty, that is, true poverty breeds true humility. Secondly, humility strengthens unity and harmony between all people, rich and poor. Thirdly, voluntary poverty almost guarantees salvation for the rich, single woman; the wealthy can gain peace in this world by giving worldly riches back to the world. Fourthly, the author returns often to the contrast between earthly riches which are uncertain and spiritual riches which endure forever. Finally, the author stresses that riches may only be kept if they are used well for the service of the Church. ${ }^{69}$ Nevertheless, as we can recognize even just from the titles of every

65 G.D. Dunn, ibid., "The Elements of Ascetical Widowhood: Augustine's De bono viduitatis and Epistula 130 ," p. 254.

66 Ps. Prosper, Epistula ad Demetriadem De Vera Humilitate, = PL 55, 161-80; K.C. Krabbe, "Epistula ad Demetriadem, De Vera Humilitate: a critical text and translation with introduction and commentary," Catholic University of America, Patristic Studies 97, Washington, DC. 1965, pp. 47-52. Even if we see only the title of every chapter, we can recognize, that the "humility" is the main theme of this letter; Cap. III."Primum himilitatis bonum, dilectionem et concordiam inter homines servare”; Cap.IV."Verum humilem, gloriam et ops saeculi fastidire ; Cap.V."Non solos pauperes, sed etiam divites humilitate Christiana ornari posse. "; Cap. VI.“Omnes sanctos Ecclesiae filios aliis rebus dispares, sola humilitate pares effici"; Cap. VII."Veram humilitatem in perfecta et integra gratiae confessione consistere."

67 Bronwen Neil, "On True Humility: An Anonymus Letter on Peverty and the Female Ascetic," in : Prayer and Spirituality in the Early Church, ed. Wendy Mayer, Pauline Allen and Lawrence Cross (The Spiritual Life, Vol. 4) Strathfield, 20o6, pp. 233-246.

68 B. Neil, ibid., p.239.

69 B. Neil, ibid., pp. 243-244. 
chapter of the letter, ${ }^{70}$ ascetic exercises of fasting and almsgiving, which the author encouraged to Demetrias, are all contracted into the humility of Christian women, that is, the humility to God and the humility to ecclesiastical authority. Pelagius also emphasized Christian humility; nevertheless, the content of the concept of "humility" was quite different from that of Ps. Prosper, just as we cited Pelagius' sentences in chapter 2; "It was another sort of humility that Christ taught us. (...) Endurance of insult reveals the truly humble".71

\section{Pelagius' Other Letters to a Widow and a Married Woman}

As we confirmed above, in emphasizing Christian women's voluntary decisions, divine instructions and future rewards, Eastern type of ascetic measure and purpose, viz. $\dot{\alpha} \pi \dot{\alpha} \vartheta \varepsilon ı \alpha$ and $\vartheta \dot{\varepsilon} \omega \sigma \iota \zeta$, Pelagius' exultations to Demetrias and Chrysostom's to Olympias are obviously quite similar. Nevertheless, Demetrias was a 14-year-old girl; on the other hand, Olympias was an adult lady when Pelagius and Chrysostom sent their letters to each addresee. Therefore, Pelagius exempted Demetrias from fasting and almsgiving as social resposibilities based on his moral critiques against the immoral situations of the Roman Church at that time. ${ }^{72}$ Pelagius encouraged Demetrias to entrust such resposibilities to her mother and grandmother. Such peculiar characteristics of Pelagius' letter to Demetrias seem to cause some differences from Chrysostom's counsels to Olympias, and also to cause Wilkinson's critique against Pelagius, saying "When Pelagius spoke of freedom he did not have in mind political freedoms or social equality". ${ }^{3}$

Nevertheless, if we read Pelagius' other letters to a widow and a married woman, we can easily recognize that Pelagius' exultations to the 14-year girl Demetrias should also be applied to adult women. Moreover, we can perceive that Pelagius' counsels to women for overcoming structural evils were obviously related to their freedoms in their social surroundings. One of Pelagius' representative works, Liber de vita christiana, is originally a letter to a Christian

70 Cap. III. "Primum himilitatis bonum, dilectionem et concordiam inter homines servare"; Cap.IV. "Verum humilem, gloriam et ops saeculi fastidire"; Cap.V. "Non solos pauperes, sed etiam divites humilitate Christiana ornari posse”; Cap. VI."Omnes sanctos Ecclesiae filios aliis rebus dispares, sola humilitate pares effici"; Cap. viı."Veram humilitatem in perfecta et integra gratiae confessione consistere."

Pelagius, ad Dem. 20.1; PL 30, 35: "Aliam nos humilitatem Christus docuit, qui nos ad exemplum suum hortatur, (...) Verum humilem patientia ostendit injuriae."

72 Pelagius, ad Dem. 22, 1 = PL 30, 36.

73 Wilkinson., p. 143. 
widow. In this letter, Pelagius lamented the deeply corrupt immoral situation of the Roman Church at that time, criticizing "nominal Christians" in the following manner.

How can you then be called a Christian, if there is no Christian act in you? (...) He is a Christian who does not know how to hate even his enemies but rather to do good to his adversaries and pray for his persecutors and enemies, following Christ's example. ${ }^{74}$

For Pelagius, "structural evils" were nothing but evils which had formerly been outside the Churches but were now inside them. Pelagius fiercely criticized the oppression of the weak in the Churches, which were caused by "nominal Christians" who did not know and even did not want to know what Christ taught his disciples. Contrary to Wilkinson's negative evaluation of Pelagius' letter to Demetrias, his letter to this widow was filled with his "political" critique against Christians, who repeated social injustice particularly against the social weak and poor people, saying "Do you consider him a Christian who oppresses the wretched, who burdens the poor, who covets others' property, who makes several poor so that he may make himself rich, who rejoices in unjust gains, who feeds on others' tears, who enriches himself by the death of the wretched (...)?"75 When we read in the letter to this widow Pelagius's describing about unjust judges who oppressed the weak and poor, we can imagine what kind of deeds Pelagius expected of the noble Christian widow.

Others again who had unjustly exterminated a countless multitude of men were torn apart limb from limb and piece by piece, so that the number of their divided members was no smaller than the number of those

74 Pelagius, Liber de vita christiana, 6,1; PL 40, 1036-1037: "Tu ergo quomodo christianus diceris, in quo nullus christiani actus? (...) Christianus ille est, qui exemplo Christi nec inimicos novit odire, sed magis adversantibus sibi benefacere, et pro persecutoribus suis et hostibus exorare."

75 Pelagius, ibid., 11, 1; PL 40, 1041: "Nam tu illum christianum putas, in quo nullus christianitatis est actus, in quo conversation nulla justitiae est, sed nequitia, impietas et scelus? Illum Christianum putas, qui opprimit miserum, qui pauperem gravat, qui res concupiscit alienas, qui ut se divitem faciat, plures efficit indigentes, qui lucris gaudet injustis, qui de alienis lacrymis cibum capit, qui miserorum ditatur interitu, cujus os assidue mendacio violatur, cujus labia nonnisi indigna et obscena et scelesta loquuntur et turpia, cui cum jubeatur distribuere sua, invadit aliena? Et ad ecclesiam talis audenter accedit, et temere et importune expandit impias manus, illicito raptu et insontium cruore violatas: et ore illo polluto atque sacrilego, quo fuerat paulo ante aut falsa locutus aut turpia, preces ad Dominum, quasi nihil sibi mali conscius fundit." 
whom they had punished and whom they had caused to be killed. And by their judgement many women were made widows when their husbands were unjustly put to death, many were left orphans by the killing of their fathers and, in addition to losing their parents, were reduced to beggary and nakedness, (...) But now their own wives are widows, and their sons are orphans and daily seek their bread form others. ${ }^{76}$

It is obviously for the purpose of overcoming such social injustice and saving such victims that Pelagius required the noble widow to live a life consistent with the example of Christ and fasting and almsgiving, although Pelagius exempted Demetrias from such ascetic responsibility because of her youth.

Reading Pelagius' letter to a married noblewoman whose name was Celantia, we can recognize that Pelagius realized such moral injustice, that is, "structural evils" came into the Church as "sin", which Christian should avoid by all means. In the context of referring to the nobility of birth, Pelagius emphasized that the Christian "religion knows nothing of the personal standings and material circumstances of individuals but examines their soul instead".77 Indicating that "the only freedom before God is freedom not be a slave to $\sin$, ${ }^{78}$ Pelagius demonstrated to Celantia that Peter, who was a fisherman and poor, and the blessed Mary, who is described as a carpenter's bride, were the noblest of people. Pelagius concluded that the nobility of high birth means nothing "when all of us without exception are reborn in Christ". ${ }^{79}$ The ultimate purpose of avoiding the immoral deeds of injustice in Christian Churches is the realization of Christ's love, which was shown us by Christ's instruction and his example.

He (Christ) wants love between us to be joined and fastened together by mutual acts of kindness, and all men to be united to one another by reciprocal love, so that while each one provides for the other what all want provided for themselves, total righteousness, as in this commandment of God, may be the common benefit of mankind. And- oh, the wonder of

$76 \quad$ Ibid., 3. 2; PL 40, 1035: "Alii autem qui innumerabilem hominum multitudinem injuste peremerant, membratim particulatimve concissi, ut non minor fuerit concisura membrorum quam quos interimi fecerant, numerous punitorum. Et quorum judicio maritis injuste peremptis muitae effectae viduae, multi orpani patribus occisis derelicti, quibus praeter orbitatem mendicitas inferebatur et nuditas : (...) nunc vero iprorum conjuges viduae et filii orphani alienis quotidie egent panibus."

Pelagius, Epistula ad Celantiam, 21; PL 22, 1214: "Nescit religio nostra personas accipere : nec conditiones hominum, sed animos inspicit singulorum."

78 Ibid., 21; PL 22, 1214: "Sola apud Deum libertas est, non servire peccatis. Summa apud Deum est nobilitas, clarum esse virtutibus."

Ibid., 21; PL 22, 1214: "cum omnes in Christo aequaliter renascamur." 
God's mercy! Oh, the ineffability of God's kindness!- he promises us a reward if we love each other, that is, if we give to each other those things of which each one of us has need in return. ${ }^{80}$

For receiving Love of God and Holy Spirit, Pelagius stressed the necessity of purifying the mind by driving out evil just as Chrysostom required of Olympias. This is nothing but $\dot{\alpha} \pi \dot{\alpha} \vartheta \varepsilon ı \alpha$ for Chrysostom, that is, imperturbabilitas for Pelagius. ${ }^{81}$ In the Letter to Celantia, where he encourages the need to set oneself in serenity, he states, "Choose a convenient place, a little removed from the noise of household, to which you can betake yourself as if to a harbour out of a great storm of cares and there, in the peace of inner seclusion, calm the turbulent waves of thoughts outside". ${ }^{82}$ Also in the other letter to Claudia, titled $D e$ Virginitate, Pelagius states: "The mind, which desires to be the dwelling place of God, should be quiet, tranquil and peaceful and far removed from anger's furious rages ('ab omni perturbatione furoris alienam')". ${ }^{3}$

Not only in the letter to young girl Demetrias but also in the letters to adult women, to a widow and to a marriage woman, we can confirm quite the same ascetic exultations of Pelagius. Moreover, we could make sure that also in those letters to aged Christian women that overcoming the structural social evils are in Pelagian thought deeply combined with the outer freedom of political and social perspective as well as with the inner freedom of holding purity of mind. Contrary to Wilkinson's critique against Pelagius, "he did not have in mind political freedoms or social equality", ${ }^{84}$ Pelagius' appeal at the end of the letter to Claudia, who received her consecration in her youth just as Demetrias, demonstrated nothing but Pelagius' conviction of political freedom or the social equality in Christ.

$80 \quad$ Ibid.,15; PL 22, 1211: "Conjungi vult inter nos, atque connecti, per mutua beneficia caritatem. Omnesque homines vicario inter se amore copulari, ut id unoquoque praestante aliteri, quod sibi ab omnibus praestari velit : tota justitia, et praeceptum hoc Dei, communis sit utilitas hominum. Et, o miram clementiam Domini! O ineffabilem Dei benignitatem! Praemium nobis pollicetur, si nos invicem diligamus, id est, si nobis ea praestemus invicem, quorum vicissim indigemus."

81 N. Yamada, "The Influence of Chromatius and Rufinus of Aquileia on Pelagius - as seen in his Key Ascetic Concepts: exemplum Christi, sapientia and imperturbabilitas," Studia Patristica, Vol, LXx, (2013), pp. 661-670.

82 Pelagius, Ad Celantiam 24; CSEL 29, 455: "Eligatur tibi oportunus et aliquantulum a familiae strepitu remotus locus, in quem tu uelut in portum quasi ex multa tempestate curarum te recipias et excitatos foris cogitationum fluctus secreti tranquillitate componassi."

83 Pelagius, De Virginitate 18; CSEL 1, 249: "Satis tranquillam et quietam esse conuenit mentem et ab omni perturbatione furoris alienam, quae Dei habitaculum esse desiderat."

84 Wilkinson., p. 143. 
Surely we are all made equal by the grace of the divine water, and there can be no distinction between those who have been created by a second birth, through which rich man as well as poor man, freeman as well as slave, the noble as well as the man of low birth is made a son of God; earthly nobility is put in the shade by the splendor of heavenly glory and can no longer match it in any respect at all, since those who in the past were unequal in worldly honours are now equally clothes in the glory of a heavenly and divine nobility. (...) or if they do so think, how vain it is for them to prefer themselves in minor matters to those whom they know to be their equals in matters of greater import, and regard as their inferiors on earth those whom they believe to be their equals in heaven! But you, who are a virgin of Christ and not of the world, must avoid and shun all the glory that is attached to this present life, in order that you may attain that glory which is promised in the world to come. ${ }^{85}$

According to D. Ford, in the Eastern Churches in Chrysostom's era, men and women stood on opposite sides of the church during services. ${ }^{86}$ This reflected the custom of daily life, in which men and women lived much more separate lives than they do today. This was one of the reasons why women's positions as deaconesses remained in Eastern regions until the end of the seventh century. Nevertheless, in the Eastern Church, in spite of Chrysostom's misogynistic idea that women were inferior to men, the path on which women could also participate in the Synergy of God's instruction through exercising their free will was still open.

85 Pelagius, De Virginitate 16, $2=\operatorname{CSEL}$ 1, 246-247: "certe omnes per diuini lauacri gratiam aequales efficimur, et nulla inter eos potest esse discretio, quos natiuitas secunda generauit, per quam tam diues quam pauper, tam liber quam seruus, tam nobilis quam ignobilis Dei efficitur filius, et terrena nobilitas splendore caelestis gloriae obumbratur et nusquam omnino iam comparet, dum qui retro in saecularibus honoribus inpares fuerant, caelestis et diuinae nobilitatis gloria aequaliter uestiuntur. (...) aut si putant, quam uanum est ut se illis in minoribus praeferant, quos sibi in maioribus pares sciunt, et quasi infra se positos in terra existiment quos sibi aequales in caelestibus credunt. tu autem, quaecumque Christi, non saeculi uirgo es, omnem praesentis uitae gloriam fuge, ut eam quae in futuro promittitur consequaris."

86 D.C. Ford, Letters to Saint Olympia, St Vladimir's Seminary Press, Yonkers, New York, 2016, p. 15 . 
Elane Pagels mentioned this feature and asserted, "Many Christian converts

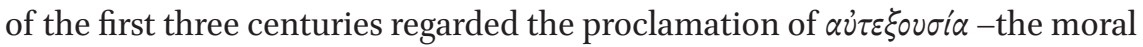
freedom to rule oneself - as virtually synonymous with "the gospel".87 Even after the first three centuries, because the substance of the gospel remained to be this $\alpha \dot{\tau} \tau \varepsilon \xi o v \sigma i \alpha$ based on human will $\pi p \circ \alpha i p \varepsilon \sigma \iota \zeta$. E. Pagels and E.S. Fiorenza, a.s.o., so-called the first generation of feminist theologians, emphasized such female alternative Christian ethos. However, in my view, recent new feminist theologians in the Western World, such as A. Jacobs (2000), and K. Wilkinson (2015), who have greatly - perhaps too greatly - broadened the range of "gender", or put another way, rely too much on their contemporary "gender theories", such as "Agency-theory", or "Modesty-theory". In doing so, their research

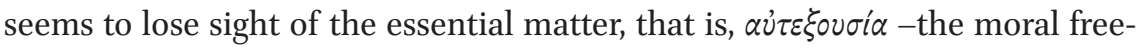
dom to rule oneself - as virtually synonymous with "the gospel". Not only Eastern Church fathers including Chrysostom but also Pelagius and his Pelagian disciples were successors of this gospel in their views of Christian women.

However, in the Western regions, not only strong ultra-misogynistic views on women like Ambrosiasters' which stressed that "women are not Imago Dei" emerged in the Roman Churches, ${ }^{88}$ but also, moreover, the emphasis on women's freedom of their own will, which belonged to the Eastern traditions, disappeared due to the excommunication of the Pelagians. Since then, women Christians in Western Churches have been situated far distant from the main sacred area of the Churches. Moreover, without being cured of their corrupted nature by Original Sin, without being overcome by the inferiority of their sexual desire, and without their submission to male religious Superiors, Western Christian women have not been guaranteed their salvation. Pelagius was most distinguished in his thinking of the equality of men and women in both the Image of God and free will.

87 E. Pagels, Adam, Eve and the Serpent, New York, 1988, p. 99.

88 D.G. Hunter, "The Paradise of Patriarchy: Ambrosiaster on Woman as (Not) God's Image," JTS n. s. 43 (1992), pp. 447-469. Hunter (p. 448) interpreted Ambrosiaster's misogynistic remarks as part of the patriarchal trend at that time: "Ambrosiaster's discomfort with asceticism and with ascetically oriented exegesis was rooted in a desire both to maintain ancient Roman tradition and to protect the prerogatives of the clergy. As such, his views represent a significant departure from previous Christian tradition, as well as a response to what he perceived as the disruptive effects of the ascetic movement." 


\section{Acknowledgement}

This study was supported by JSPS (Japan Society for the Promotion of Science) 'Kakenhi (Grant-in-Aid for Scientific Research (C) (2018): the research number is [15Ko2088])' and also by Nanzan University Pache Research Subsidy I-A-2 (2019 academic year). 